\title{
EYE-LENS DOSE COEFFICIENTS: A SIMULATION STUDY COMPARING OPERATIONAL DOSE USING MCNP AND GEANT4 MONTE CARLO SIMULATION CODES
}

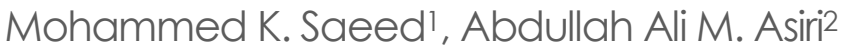

\begin{abstract}
Department of Radiological Sciences, Applied Medical Sciences College, Najran University. Najran, Saudi Arabia.

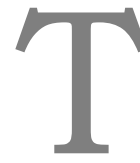
he aims of this work include evaluating the capability of the GEANT4 Monte Carlo code to describe electron dose coefficients for eye-lens using ICRU tissue cylindrical phantoms and comparing the results with Monte Carlo N-Particle (MCNP) and MCNPXTM data retrieved from the literature. A few years back, the International Commission on Radiological Protection (ICRP) issued a statement to lower the eye dose occupational annual dose limit. Therefore, efforts have increased globally in this regard using dose simulation to calculate the eye-lens dose coefficients.

Materials and methods. Three scattering models provided by GEANT4 (Urban, Wentzel-VI and Goudsmit-Saunderson) were used in this work to calculate the electron eye-lens dose coefficients.

Results. It became clear from this study that choosing of the scattering model has a strong influence for electron energies at $1 \mathrm{MeV}$ and below.

Conclusion. The use of the Urban scattering model with GEANT4 may be preferred as it was earlier reported to best represent experimental measurements. However, the description of electron dose coefficients at $3 \mathrm{~mm}$ depth deserves further consideration at these energies levels.
\end{abstract}

Keywords: GEANT4, scattering models, eye-lens dose coefficients, $\mathrm{Hp}(3)$.

Corresponding author: Mohammed K. Saeed, e-mail: aaalasmy@nu.edu.sa

For citation: Mohammed K. Saeed, Abdullah Ali M. Asiri. Eye-lens dose coefficients: a simulation study comparing operational dose using MCPR and GEANT4 Monte Carlo simulation codes. REJR 2021; 11(4):122-128. DOI: 10.21569/2222-7415-2021-11-4-122-128.

Received: $\quad 12.10 .21 \quad$ Accepted: $\quad 02.12 .21$

\section{АОЗОВЫЕ КОЭФФИЦЕНТЫ АЛЯ ХРУСТААИКА ГААЗА: СРАВНИТЕАЬНОЕ ИССАЕАОВАНИЕ ИНАИВИАУАЛЬНЫХ ЭКВИВААЕНТНЫХ АОЗ МЕТОАОМ МАТЕМАТИЧЕСКОГО МОАЕАИРОВАНИЯ ПРИ ИСПОАЬЗОВАНИИ ПАКЕТОВ ПPOГPAMM MCNP И GEANT4}

\author{
Mохаммен K. Сай', Аблул^а Али М. Асири²
}

\begin{abstract}
Отделение радиологических наук, Комеедж прикладньх медицинских наук, Наджранский университет. Наджран, Саудовская Аравия.
\end{abstract}

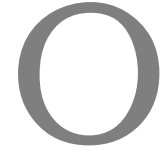

ценка способности программы GEANT4 Monte Carlo характеризовать коэффициенты потока эмектронов для хрусталика глаза с использованием цилиндрических тканеэквивалентных фантомов ICRU и сравнение результатов с данными Monte Carlo NParticle (MCNP) and MCNPXTM, полученными из митературы. Несколько мет назад Международная комиссия по радиологической защите (ICRP) выпустила заявление о снижении предельной годовой дозы для глаз. В связи с этим, во всем мире активизировались усилия по использованию моделирования дозы дмя расчета коэффициентов дозы облучения хрусталика 


\section{RUSSIAN ELECTRONIC JOURNAL OF RADIOLOGY}

глаза.

Материалы и методы. Три модели рассеивания пучка, предоставленные GEANT4 (Urban, Wentzel-VI и Goudsmit-Saunderson), были использованы в этой работе для расчета коэффициентов дозы облучения хрусталика глаза.

Результаты. Из этого исследования стало ясно, что выбор модели рассеивания пучка оказывает сильное влияние на энергию электронов при 1 МэВ и ниже.

Выводы. Использование модели рассеивания пучка Urban с GEANT4 может быть более предпочтительнее, поскольку, как сообщалось ранее, она мучше всего подходит дмя представления экспериментальных данных. Однако, описание коэффициентов дозы облучения на глубине 3 мм заслуживает дальнейшего рассмотрения на этих уровнях энергии.

КАючевые слова: GEANT4, модели рассеивания пучка, дозовые коэффициенты хрусталика глаза, Нр (3).

Контактный автор: Мохаммед К. Саид, e-mail: aaalasmy@nu.edu.sa

Для иитирования: Мохаммед К. Саид, Абдулла Али М. Асири. Дозовые коэффииенты для хрусталика глаза: сравнительное исследование индивидуальных эквивалентных доз методом математического моделирования при использовании пакетов программ MCNP u GEANT4. REJR 2021; 11(4):122-128. DOI: 10.21569/2222-7415-2021-11-4-122-128.

Статья получена: $\quad 12.10 .21 \quad$ Статья принята: $\quad 02.12 .21$

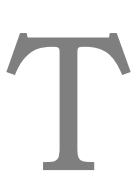

he eye lens is one of the most radiosensitive tissues in the body $[1,2]$. In this regard, in 2012, the International Commission on Radiological Protection (ICRP) has issued a statement to reduce the equivalent eye lens dose occupational annual dose limit from 150 to $20 \mathrm{mSv}$ y-1[3]. Thus, the dose limit to the eye lens has reduced for nuclear workers by a factor of almost 10 , which formed many challenges and practical considerations on the estimation of occupational eye dose.

According to the Directive European Atomic Energy Community (EURATOM) 1996/29, measuring the equivalent dose to the lens of the eye $\mathrm{Hp}(3)$ and extremities $\mathrm{Hp}(0.07)$ should carry out at a depth of 3 and $0.07 \mathrm{~mm}$, respectively [4]. Direct eye lens dosimeter supporting with an adjustable headset, to assess the $\mathrm{Hp}(3)$, was reported in the literature [5]. If these dosimeters are unavailable, other methods can be used such as retrospective dose evaluation based on the level of scatter radiation or correlations between the eye lens dose to the workers [6].

Before more than two decades, for $\mathrm{Hp}(3)$, a slab phantom made of water-filled polymethyl methacrylate (PMMA) and ICRU tissue has been suggested for calibration purposes and the calculation of conversion coefficients, respectively [7]. However, in the past decade, a cylinder phantom was recommended as it much better approximates the appearance of a human head. The cylinder phantom was made also of water-filled PMMA for calibrations and made of ICRU tissue for the calculation of conversion coefficients [8-11].

Since 2009-2010, for goals of radiation protection, new eye-lens doses electron and photon protection coefficients, based on a precise eye model, have been available in the literature [1213]. In 2017, Behrens presented an excellent compendium of protection coefficients [14].

The introduction of operational lens-dose coefficients depends largely on efforts made to improve the monitoring of the eye-lens dose in the medical field such as interventional radiology, nuclear medicine and new developments [15]. In this regard, the international collaboration group ORAMED Contract (Optimization of RAdiation protection for MEDical staff) has worked to enhance methodologies for better evaluating and decreasing exposures to medical staff, for examinations resulting to potentially high doses or complex radiation fields. Furthermore, this collaborationreported tables of air kerma (ka) to dose conversion coefficients, $\mathrm{Hp}(3) / \mathrm{ka}$, calculated as the dose at 3 $\mathrm{mm}$ depth in a cylindrical phantom that recommended by the ICRU in 1998 [7]. However, the occupational radiation dose of the eye-lens in the nuclear industry field is a concern of many due to beta radiation. Currently, studies on the electron operational dose coefficients $\mathrm{Hp}(3) / \Phi$ in an ICRU cylindrical phantom are scanty. Coefficients tables are reported by Ferrari et al. in 2012 [16]. Behrens also has compared slab and cylinder phantoms, to determine which is more appropriate to estimate the $\mathrm{Hp}(3)$ eye lens dose[17]. Dubeau and Sun had 
used, for their calculation, the Monte Carlo NParticle (MCNP) code package version 5, whereas, Ferrari et al. had used MCNPXTM simulation code $[15,18]$. We wish in this work to confirm their findings. In addition, and as a continuation of their effort, this work investigates the effects of the electron transport models using GEANT4 simulation code on the $\mathrm{Hp}(3) / \Phi$ coefficients.

\section{Methods.}

Overview of the simulation configuration.

This work was performed with version 9.2.p01 of the GEometryANd Tracking 4 (GEANT4)[19]. Differentscattering models, which describes electron and photon interactions in a wide energy range (1 keV-100 TeV), was used in all simulations. Separate runs were accomplished for beam of mono-energetic electrons ranging in energy between 0.8 and $10 \mathrm{MeV}$.

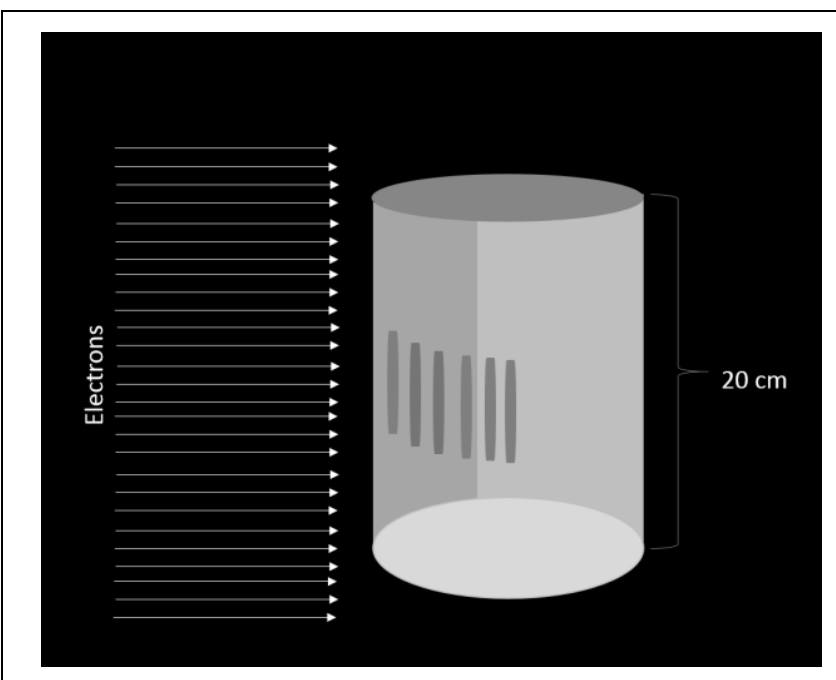

Fig. 1 (Рис. 1)

Fig. 1. Scheme.

Simplified schematic of the geometrical model of the cylindrical phantom (generated by MS-PowerPoint Ver. +2013)

\section{Рис. 1. Схема.}

Упрощенная схема геометрической модели цилиндрического фантома (создана в MS-PowerPointVer. +2013).

The energy deposition has calculated at a depth of $3 \mathrm{~mm}$ in a cylindrical phantom of $20 \mathrm{~cm}$ diameter and $20 \mathrm{~cm}$ height (Fig. 1). The phantom consist of ICRU tissue which a composition of $10.1 \% \mathrm{H}, 11.1 \% \mathrm{C}, 2.6 \% \mathrm{~N}$ and $76.2 \% \mathrm{O}$ with a mass density of $1.0 \mathrm{~g} \cdot \mathrm{cm}-3$. The phantom has exposed to a field size of $24 \times 24 \mathrm{~cm} 2$ cross-section of parallel electrons beam, which was calculated later by scoring the energy deposited per source particle in thin 'slices' volumes $(0.5 \mathrm{~cm}$ wide and 4 $\mathrm{cm}$ long). The slices volumes have used as a detector in this work. In other words, energy deposition in each slice was scored by using the methods
GetPosition() and GetEnergyDeposit() of GEANT4. For all tracked particles, the step position obtained with the GetPosition() method has utilized to check whether the particle was inside or outside the detector volume. The primary slice was placed directly in front of the beam at $0 \circ$ while other slices have placed at different angles (15॰, $30^{\circ}, 4^{\circ}, 60^{\circ}$ and $75^{\circ}$ ) with respect to the direction of incidence of the electrons. A total of 1 million source particles have run for each case per simulation (statistical uncertainty of $0.23 \%$ ).

\section{Electron Transport in GEANT4.}

The electron transport method used by GEANT4 hasextensively described in the user manual[20]. The GEANT4 toolkit offers several scattering models applicable to different particles in a wide energy range, and it has summarized by Donderoet al. [21]. It is then relevant to summarize here the principal features of the electron transport processes used by Geant4.

During transport, typically electrons undergo a large number of interactions that diminish their energies such as knock-on electron production, continuous slowing down, atomic excitation with the emission of X-rays and Auger electrons and bremsstrahlung production. It is worth mentioning that the electron multiple-scattering model used by default in GEANT4 version 9.3.p01 is the Urban multiple scattering model,Urban2 model,[20], and is belong to a class II condensedhistory algorithm as reported by Berger [22]. The Urban model is appropriate to any particle, but the recent GEANT4 versions used only for electrons, positrons and ions. It uses an algorithm of probability density functions for sampling the spatial and angular distributions after each electron step. The model based on the Lewis theory, and it has been adopted in this work because they give the same moments of the angular and spatial distributions [23]. Lewis theory is appropriate for all scattering angles, and it enables electron step sizes to be arbitrarily small.

In addition to the Urban model, two additional models have used in this work: (a) Combined multiple and single scattering model (Wentzel-VI model) and (b) Goudsmit-Saunderson multiple scattering model (Goudsmit-Saunderson model). The Wentzel-VI modelcan be used with low CPU usage for all charged particles and all energies, except electron and positron below $100 \mathrm{MeV}$. Regarding Goudsmit-Saunderson model, it's using some algorithms of the EGSnrc multiple scattering model developed byKawrakow and Bielajew[24] and based on Goudsmit-Saunderson theory [25]. In this model at each step, a sampling of no scattering, single or multiple is performed for negatrons and positrons depending on the number of interactions along the path.

Unlike many other simulation codes, all 


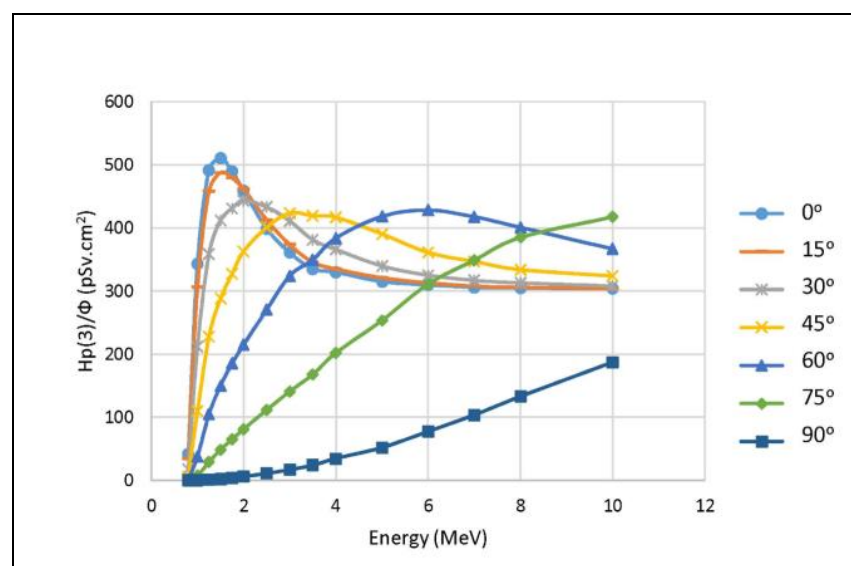

Fig. 2 (Рис. 2)

\section{Fig. 2. Diagram.}

Mean equivalent dose per electron fluence using GEANT4-Urban for 0 。 incidence and for other angles.

\section{Рис. 2. Аиаграмма.}

Средняя эквивалентная доза по плотности потока электронов с использованием GEANT4-Urban для угма падения $0^{\circ}$ и других угмов.

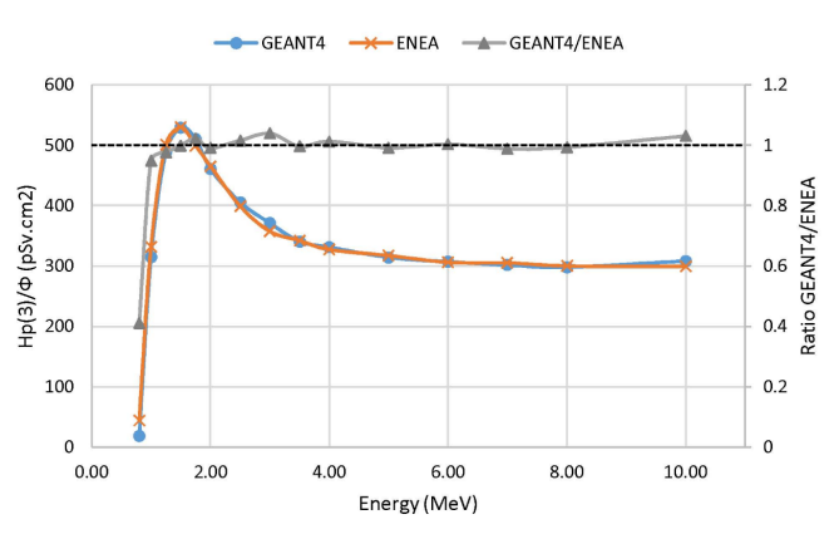

Fig. 3 (Рис. 3)
Fig. 3. Diagram.

Mean equivalent dose per electron fluence for 0 。 incidence calculated with GEANT4-Wentzel-VI (this work) and those of ENEA [16].

\section{Рис. 3. Аиаграмма.}

Средняя эквивалентная доза по плотности потока эмектронов дия угла падения $0^{\circ}$, рассчитанная с помощью GEANT4-Wentzel-VI (данное исследование) и ENEA [16]. particles (primary and secondary) created in GEANT4 are in origin tracked to the end of their range. Nevertheless, the user can define the number of secondary particles to be tracked, by blocking the production of secondary particles whose range would be less than a user-defined value called the 'range cut' [19-20]. A range cut of 3.3 $\mu \mathrm{m}$, corresponding to electron energy of $\sim 2 \mathrm{keV}$ in ICRU tissue, was used for incident energies $>0.8$ $\mathrm{MeV}$. The ROOT system analysis tool was utilized to obtain the relevant dosimetric quantities from the results.

In GEANT4, the algorithm of particle transport contains four levels: event, track, step and run [20]. These levels are well described in the user manual [26], and it has been summarized by Maigne et al. [27]. The event level is concerned with the simulation of a single history. While the run level is the topmost level at which overall control of running a pre-defined number of histories is managed.

\section{Results.}

Fig. 2 shows the calculated electron fluence to dose coefficients using GEANT4. Based on the entire lens, the eye lens dose depending on the electron energy for angles of incidence of $\square=0^{\circ}$, $15^{\circ}, 30^{\circ}, 45^{\circ}, 60^{\circ}, 75^{\circ}$, and $90^{\circ}$. These coefficients have calculated using the Urbanmultiple scattering model.

Fig. 3 shows the coefficients obtained in this work using GEANT4-Wentzel-VI and those of EnergiaNucleareedEnergie Alternative, ENEA, [16] for $0 \circ$ incidences. In addition, Fig. 3 shows the ratios of the ENEA set calculated with MCNPXTM and data of this work. The coefficients in the energy range from 0.8 to $10 \mathrm{MeV}$ varied between 18 and 308 pSv.cm2. It is evident, from Fig. 3, that both two data sets are comparable above the energy of $2 \mathrm{MeV}$. However, significant variation can be observed at $1 \mathrm{MeV}$ or below this value. It is worth mentioning that this region is meaningful as beta particles have noticed with energies spanning a continuum.By comparison, the ENEA coefficients exceed those of this work by a factor of 0.4 at $0.8 \mathrm{MeV}$ and $5 \%$ at $1 \mathrm{MeV}$.

The effect of the selecting of the scattering model,described previously, was evaluated and ledto the results of Table 1 . It seems that the choice of the scattering model has a strong influence for electron energies at $1 \mathrm{MeV}$ and below. Table 2 shows a comparison between the data of $\mathrm{Hp}(3, \mathrm{a})$ dose coefficients reported by ENEA [16], ICRP74 [28], MCNP [15] and the results of GEANT4 obtained in this work using Urban, Wentzel-VI and Goudsmit-Saunderson models. It can be observed generally good agreement at 1 $\mathrm{MeV}$, whereas GEANT4 (Wentzel-VI and Goudsmit-Saunderson) gives a much lower coefficient at $0.8 \mathrm{MeV}$.

Discussion. 


\begin{tabular}{|c|c|c|c|c|c|}
\hline \multicolumn{6}{|c|}{$\begin{array}{c}\text { Table №1. Impac } \\
\text { MCNP step-specific [15]. }\end{array}$} \\
\hline $\begin{array}{l}\text { Energy } \\
(\mathrm{MeV})\end{array}$ & Scattering model & Model class & Process class & $\begin{array}{l}\text { Range } \\
\text { Factor }\end{array}$ & $\begin{array}{c}\frac{H_{p}}{\Phi} \\
\left(\mathrm{pSv} \cdot \mathrm{cm}^{2}\right)\end{array}$ \\
\hline 1.0 & Urban & G4UrbanMscMode & G4eMultipl-eScattering & default & 343 \\
\hline 1.0 & Wentzel-VI & G4WentzelVIModel & G4eMultipl-eScattering & 0.02 & 315 \\
\hline \multirow[t]{3}{*}{1.0} & $\begin{array}{l}\text { Goudsmit- } \\
\text { Saunderson }\end{array}$ & $\begin{array}{l}\text { G4GoudsmitSaunderson } \\
\text { Model }\end{array}$ & G4eMultipl-eScattering & 0.02 & 331 \\
\hline & MCNP step-specific & & & & 305 \\
\hline & ENEA & & & & 332 \\
\hline 0.8 & Urban & G4UrbanMscMode & G4eMultipl-eScattering & default & 42 \\
\hline 0.8 & Wentzel-VI & G4WentzelVIModel & G4eMultipl-eScattering & 0.02 & 18 \\
\hline \multirow[t]{3}{*}{0.8} & $\begin{array}{l}\text { Goudsmit- } \\
\text { Saunderson }\end{array}$ & $\begin{array}{c}\text { G4GoudsmitSaunderson } \\
\text { Model }\end{array}$ & G4eMultipl-eScattering & 0.02 & 39 \\
\hline & MCNP step-specific & & & & 30 \\
\hline & ENEA & & & & 44 \\
\hline
\end{tabular}

In this study, we have investigated the effects of the electron transport models using GEANT4 simulation code on the $\mathrm{Hp}(3) / \Phi$ coefficients. This paper addresses the question, how well can GEANT4 be employed to confirm the findings of previous MCNPX studies $[15,18]$ to obtain the Hp(3)/ $\Phi$ coefficients? To answer this, GEANT4 have been employed to simulated cylindrical phantom consists of ICRU tissue, as well as to simulate mono-energetic parallel electron beam source geometries. As previously mentioned, three scattering models provided by GEANT4 were used to find the most close model to ENEA Hp(3)/Ф coefficients results.

A few comparisons have conducted between MCNPX, GEANT4 regarding simulations of photon and neutron transport through different materials [29], whereas comparisons of electron transport between these packages are scarce. In general, using MCNPX code consider easier than GEANT4, where most of the new users spend a substantial effort in learning the $\mathrm{C}++$ programming language before they can effectively use GEANT4 code. However, nowadays several software frameworks have been developed such as GATE [30], or PTSIM and TOPAS [31] that make a wide range of GEANT4 functionality available through a user-friendly interface in the Medical Physics field.

The dose coefficients obtained in this study and of theENEA were for a cylindrical phantom using ICRU tissue (Table 2).It is predicted that, for 0 。 incidence electrons, thedose coefficients ob- tained by the cylindrical phantom should very nearly equal those of the slab phantom. In this second situation, accepted $\mathrm{Hp}(3) / \Phi$ coefficients are found in ICRP publication 74 [28], which have obtained from a previous study [32]. As previously mentioned in the Result section, Table 4 compares the results from these different sources. In general, there is a good agreement between the coefficients calculated in this work using the three scattering models of GEANT4 and previously published studies. However, significant variations have observed at $0.8 \mathrm{MeV}$.One practical outcome is that the GEANT4 Wentzel-VI model may give dose coefficients that are lower by as much as $9 \%$ than with the other two scattering models for energies of $1 \mathrm{MeV}$ (Table 2).

As the simulation of backscattering is a sensitive playground to assess the capability of a Monte Carlo transport code to represent electron multiple scattering correctly, Kim et al. also observed large variability in the performance of all models over the range of Geant4 versions [33]. They noticed that Urban are faster comparing with the Wentzel-VI model. Furthermore, they demonstrated that the energy deposited in a lead target using the Urban model is higher comparing to Wentzel model.

Most of these variations between scattering models can be attributed to the presence of systematic influences such as prepackaged PhysicsLists, selected data libraries (Evaluated Electron Data Library and Evaluated Photon Data Library) and energy indexing algorithm that are af- 
Table №2. Comparison between the data of $\mathrm{Hp}(3, \mathrm{a})$ dose coefficients reported by ENEA [16], ICRP74 [28], MCNP [15] and GEANT4results obtained in this work.

\begin{tabular}{ccccccc}
\hline & & & & \multicolumn{3}{c}{ GEANT4 $\left(\mathrm{pSv} . \mathrm{cm}^{2}\right)$} \\
$\begin{array}{c}\text { Energy } \\
(\mathrm{MeV})\end{array}$ & $\begin{array}{c}\text { ENEA } \\
\left(\mathrm{pSv} . \mathrm{cm}^{2}\right)\end{array}$ & $\begin{array}{c}\text { ICRP74* } \\
\left(\mathrm{pSv} . \mathrm{cm}^{2}\right)\end{array}$ & $\begin{array}{c}\text { MCNP } \\
\left(\mathrm{pSv} . \mathrm{cm}^{2}\right)\end{array}$ & Urban & Wentzel-VI & $\begin{array}{c}\text { Goudsmit- } \\
\text { Saunderson }\end{array}$ \\
\hline 10 & 299 & 303 & 305 & 304 & 308 & 301 \\
8 & 300 & 305 & 306 & 305 & 298 & 303 \\
7 & 305 & 306 & 306 & 306 & 301 & 305 \\
6 & 306 & 309 & 310 & 310 & 307 & 308 \\
5 & 317 & 317 & 316 & 315 & 314 & 313 \\
4 & 327 & 334 & 332 & 330 & 331 & 327 \\
3.5 & 342 & 351 & 338 & 335 & 340 & 333 \\
3 & 357 & 373 & 362 & 361 & 371 & 359 \\
2.5 & 399 & 417 & 398 & 399 & 405 & 401 \\
2 & 465 & 481 & 460 & 459 & 461 & 456 \\
1.75 & 499 & 512 & 491 & 490 & 510 & 489 \\
1.5 & 530 & 524 & 513 & 511 & 529 & 509 \\
1.25 & 501 & 486 & 493 & 492 & 489 & 491 \\
1 & 332 & 301 & 342 & 343 & 315 & 331 \\
0.8 & 44 & 45 & 41 & 42 & 18 & 39 \\
\hline *slab phantom & & & & & & \\
\hline
\end{tabular}

fecting the energy deposition for electrons whose range is beside or just above the $3 \mathrm{~mm}$ depth. As an overall trend, one should consider carefully the coefficients that are used for those cases pending further modelling.

One is also cautioned toconsider carefully that there is several variants of Urban model have been released in the course of the evolution of Geant4, such as G4UrbanMscMode196, G4UrbanMscMode195, G4UrbanMscMode193, G4UrbanMscMode192, G4UrbanMscModel2, G4UrbanMscMode190, G4MscModel71, G4UrbanMscModel and G4MscModel, which are outside the scope of this paper.

\section{Conclusion.}

This paper has analyzed the capabilities of GEANT4 to calculate the $\mathrm{Hp}(3) / \Phi$ coefficients. It seems that the description of electron dose coefficients at $3 \mathrm{~mm}$ depth in the ICRU tissue phantoms deserves further consideration at energies at
$1 \mathrm{MeV}$ and below. The use of the Urban scattering model with GEANT4 may be preferred as it was earlier reported to best represent experimental measurements.

Ethics approval and consent to participate.

All procedures involving human participants were performed in accordance with the ethical standards of the institutional committee, as well as the 1964 Helsinki Declaration and its later amendments or comparable ethical standards. This article does not contain any animal or human experiments. This work was approved by the ethic committee (reference no: NajranUniversitySaudi Arabia: NU-2020-642).

\section{Funding.}

No funding to disclose.

Conflict of interests.

No conflict of interest. Informed consent was obtained.

\section{References:}

[1]. Rehani MM,Vano E, Ciraj-Bjelac O, Kleiman N J. Radiation and cataract.RadiatProt Dosimetry.2011; 147: 1-2.

[2]. AinsburyEA, Bouffler SD, Graw WJ,MuirheadCR, Edwards A, Cooper J. Radiation cataractogenesis: a review of recent studies.Radiat Res.2009; 172: 1-9.
[3]. International Commission on Radiological Protection (2011) ICRP-statement on tissue reaction, ICRP ref 4825-3093-1464, Oxford: Pergamon Press

[4]. Basic Safety Standards (1996) Council of the European Union, Directive 96/29/Euratom 


\section{RUSSIAN ELECTRONIC JOURNAL OF RADIOLOGY}

[5]. HagaY, Chida K,Kaga Y, Sota M, Meguro T,Zuguchi M. Occupational eye dose in interventional cardiology procedures.Sci Rep.2017; 7:569

[6]. Rehani MM. Eye dose assessment and management: overview.RadiatProtDosim. 2015; 165:276-278

[7]. International Commission on Radiation Units and Measure ments (1998) Conversion coefficients for use in radiological protection against external radiation. ICRU report 57, os29(2)

[8]. DauresJ, GouriouJ, Bordy J-M.Monte Carlo determination of the conversion coefficients $\mathrm{Hp}(3) / \mathrm{Ka}$ in a right cylinder phantom with PENELOPE code. Comparison with 'MCNP' simulations.RadiatProtDosim.2011;144: 37-42

[9]. BordyJ-M, Gualdrini G,Daures J, Mariotti F.Principles for the design and calibration of radiation protection dosemeters for operational and protection quantities for eye lens dosimetry.RadiatProtDosim.2011;144: 257-261

[10]. Gualdrini G. et al.A new cylindrical phantom for eye lens dosimetry development.Radiat Meas.2011;46: 1231-1234

[11]. Optimization of RAdiation protection of MEDical Staff (2020) Project within the 7thframework programme of the European Union (www.oramed-fp7.eu/en)

[12]. Behrens R, Dietze G, Zankl M. Dose conversion coefficients for electron exposure of the human eye lens (corrigendum).Phys Med Biol. 2010;55: 3937-3945

[13]. Behrens R, Dietze G. Dose conversion coefficients for photon exposure of the human eye lens. Phys Med Biol.2011;56: 415-437

[14]. Behrens R.Compilation of conversion coefficients for the dose to the lens of the eye. RadProtDosim.2017;174: 348-370

[15]. Dubeau J, Sun J.Electron eye-lens operational dose coefficients. Rad ProtDosim.2020;188(3): 372-377

[16]. FerrariP, Gualdrini G (2012)Eye lens dosimetry for electrons. ENEA report RT/2012/6/ENEA

[17]. Behrens R.On the operational quantity $H p(3)$ for eye lens dosimetry. JRadiol Prot.2012;32: 455-464

[18]. Pelowitzed DB (2011) MCNPXTM user's manual. LACP-1100438

[19]. Agostinelli S. et alGEANT4: a simulation toolkit.Nuclinstrum MethodsA.2003;506:250-303

[20]. GEANT4 Collaboration 2008a Physics Reference Manual (2008) Version: GEANT4 9.2http://geant4.web.cern.ch/geant4/UserDocumentation/User sGuides/PhysicsReferenceManual/html/PhysicsReferenceManual.html[accessed 2-4 October 2020].
[21]. DonderoP, Mantero A, Ivanchencko V, Lotti S, Mineo T, Fioretti V.Electron backscattering simulation in Geant4.Nuclear Inst, and Methods in Physics Research B.2018;425:18-25

[22]. Berger MJ (1963)Monte-Carlo calculation of the penetration and diffusion of fast charged particles, Methods in Computational Physics: Advances in Research and Applications 1, New York: Academic

[23]. Lewis HW.Multiple scattering in an infinite medium. Phys Rev.1950;78: 526-529

[24]. KawrakowI, BielajewAF.On the representation of electron multiple elastic-scattering distributions for Monte Carlo calculations.Nuclinstr Meth Phys ResSect B.1998; 134: 325-336

[25]. Ivanchenko VN, Kadri O, Maire M, Urban L.Geant4 models for simulation of multiple scattering. $J$ Phys: Conf Ser.2010;219(3):32-45

[26]. GEANT4 Collaboration 2008b Users Guide Version (2008) GEANT4 9.2;

http://geant4.web.cern.ch/geant4/geant4_public/source/geant 4/examples/extended/electromagnetic/TestEm12/README[ac cessed 4 February 2021]

[27]. MaigneL, Perrot Y, Schaart DR, DonnarieixD, Breton V.Comparison of GATE/GEANT4 with EGSnrc and MCNP for electron dose calculations at energies between $15 \mathrm{keV}$ and 20 MeV. Phys Med Biol.2011;56: 811-827

[28]. International Commission on Radiological Protection (1996) In: Conversion coefficients for radiological protection quantities for external radiation exposures, ICRP Publication 74, Ann. ICRP

[29]. Lemrani R, Robinson M, Kudravtsev VA, DeJesus M, Gervier G, Spooner NJC.Low-Energy Neutron Propagation in MCNPX and GEANT4.Nuclinstrum Meth A.2006;560(2):454-459

[30]. JanS, Morel CGATE: a simulation toolkit for PET and SPECT. Phys Med Biol.2004;49: 4543-4561

[31]. AsoT. et al. PTSim and TOPAS, Geant4 in the particle therapy clinic, in: Proceedings of the SNAPMC, Progress in Nuclear Science and Technology.2011;2: 912-917

[32]. ChartierJLet al.Reference fluenceto-dose-equivalent conversion coefficients and angular dependence factors for 4-element ICRU tissue, water and PMMA slab phantoms irradiated by broad electron beams. RadProtDosim. 1996;63(1): 7-14

[33]. KimSH, Pia MG, Basaglia T, Han MC, Hoff G, Kim $\mathrm{CH}$,Saracco P.Validation test of geant4 simulation of electron backscattering. IEEE transactions on nuclear science.2015;62:451-479. 